Ivana S. Milojević*

$811.163 .41^{\prime} 37 ; 811.14{ }^{\prime} 06 ' 37$

doi 10.18485/analiff.2015.27.2.13

\title{
FRAZEOLOŠKE JEDINICE SA KOMPONENTOM RUKA U SRPSKOM I GRČKOM JEZIKU
}

Jedan od najzastupljenijih somatizama u gotovo svim jezicima jeste somatizam ruka koji je, kao predmet našega rada, kontrastivno analiziran u dva genetski nesrodna jezika - polaznom srpskom i ciljnom grčkom. Kako je već utvrđeno, izučavanje somatizama u okviru frazeologije je od izuzetnog značaja, pošto se na taj način otkriva i sagledava čovekov unutrašnji svet, mesto čoveka u njemu kao i odnos čoveka prema samome sebi. Iz toga razloga somatizmi sadrže veliki semantički potencijal u kreiranju frazeologizama kao posebno markiranih i izuzetno ekspresivnih jezičkih jedinica, sklopova različitih leksema, koje zajedno nose novo značenje a koje nije uvek lako razotkriti i protumačiti.

Otuda je osnovni cilj ovog rada da putem kontrastivne analize ukaže na sličnosti i razlike u navedenim jezicima preko frazeologizama sa komponentom $r u k a / \chi \chi^{\prime} \rho l$, utvrdi o kakvom je tipu ekvivalencije reč, kao i klasifikuje FJ na osnovu konceptualne analize putem pozitivnih i negativnih semantičkih polja. Somatizme smo ekscerpirali iz uglavnom jednojezičnih rečnika srpskog i grčkog jezika. Oslanjajući se na dobijene rezultate, može se zaključiti da su srpski i grčki jezik, posmatrani preko ove odabrane lekseme, u najvećem broju slučajeva frazeološki sasvim bliski, što je sasvim očekivano, budući da ulaze u sastav balkanskog jezičkog areala i opšteg balkanskog načina razmišljanja i poimanja. Sa druge strane, u svakom jeziku uočeni su i frazeološki obrti sa nultim stepenom ekvivalencije, što je sasvim razumljivo i očekivano, s obzirom da nijedan narod, ma koliko bio blizak drugome u društvenom i kulturno-civilizacijskom pogledu, ne sagledava niti doživljava na isti način određene pojave, činjenička stanja.

Ključne reči: somatizam, $r u k a / \chi \varepsilon ́ p l$, kontrastivna analiza, konceptualna analiza, pozitivno semantičko polje, negativno semantičko polje, grčki jezik, srpski jezik.

\section{Uvod}

U poslednjih nekoliko decenija se u nauci o jeziku na frazeologiju posmatra kao jedan od najvažnijih izvora za rekonstrukciju jezičke slike

\footnotetext{
* Univerzitet u Beogradu, Filološki fakultet, Katedra za neohelenske studije, Stu-
} denstki trg 3, 11000 Beograd. Elektronska adresa: ivana.milojevic@fil.bg.ac.rs 
sveta, budući da je realni svet, koji se odražava u frazeologiji, zasnovan na našem iskustvu, stereotipima, nasleđenim predstavama o pojavama u objektivnom svetu, gde u prvi plan najčešće istupaju etaloni ili slikovite predstave zasnovane na preterivanju (Mršević-Radović 2008: V-VII).

Kako je s pravom istakao Simeonidis ( $\Sigma u \mu \varepsilon \omega v i ́ \delta \eta \varsigma, 2000: 54-56)$, čovek i njegovo okruženje zauzimaju značajno mesto u frazeologiji. Čovek svoj trag ostavlja putem običaja, navika, ponašanja, želje, emocije, religiozne, umetničke i društvene percepcije i teorija. Polja iz kojih potiču slike i metafore u grčkoj frazeologiji pružaju informacije o tome koji se antropološki fenomeni, uključujućí i one iz njegovog okruženja, tiču čoveka, koja iskustva i pojave koristi kako bi čovek jezički ispoljio svet. Lekseme koje su najznačajnije za generisanje frazeoloških izraza klasifikovane su po semantičkim poljima:

1) delovi tela i organi;

2) okruženje;

3) društveni život;

4) život, vreme;

5) religiozni pojmovi;

6) običaji, emocije, i

7) osnovne aktivnosti.

Od svih delova ljudskog tela ruka, zajedno sa glavom i okom, predstavljaju jedan od najfrekventnijih somatizama opšte rasprostranjenosti. Delovi tela, kao i organi (unutrašnji i spoljašnji), svakako su najzastupljenije frazemotvorne sastavnice, ne samo u grčkom jeziku, već su duboko ukorenjene i u osnovni leksički fond svih slovenskih jezika (Dragićević, 2007).

Izučavanje somatizama je od izuzetnog značaja zbog njihovog velikog semantičkog potencijala u kreiranju frazeologizama. Izazov je izučavati somatizme, budući da je reč o jednom od možda najstarijih frazeoloških slojeva ${ }^{1}$ u bezmalo svakom jeziku, ali ujedno i o najbrojnijoj grupi frazeologizama koje iskazuju brojne čovekove fizičke i karakterne

1 Ova naša pretpostavka se zasniva na važnoj činjenici - da je čovek od samog početka svog evolutivnog razvoja pa do danas bio i ostao čvrsto upućen na svoje telo koje mu pomaže da opstane kao biće. Kada je reč o ruci i o njenom posebnom značaju i ulozi u formiranju čoveka, napisane su do danas brojne atropološke studije koje dovode u tesnu vezu pojavu i razvoj senzomotorike kod čoveka, formiranje svesti, apstraktnog razmišljanja, a samim tim i jezika, itd. sa rukom (cf: Ashley-Montague, 1931; Clark, 1934; Hooton, 1931; Huxley, 1930; Schultz, 1936; Thieffry, 1973; Wehr, 1999; Wilson, 2002). 
osobine, emocije i psihološka stanja, moralne vrednosti itd. „Somatizmi u strukturi najvećeg broja frazeoloških jedinica svedoče o nekim ekstralingvističkim činjenicama koje su bitne za njihov nastanak. Naime, proces ljudske spoznaje stvarnosti počinje od opažanja preko organa percepcije, jer od čovekova nastanka, sopstveno telo je najdostupniji objekat interesovanja i posmatranja. Zbog toga je prirodno da je čovek svoju orijentaciju u prostoru, svoj odnos prema okolini i sl. najlakše determinisao prema delovima svog tela. Nije slučajno što su delovi tela služili kao jedinice merenja daljine, težine, visine itd., ali i kao razni orijentiri““ (Mušović 2002: 4-5).

Budući da su frazeologizmi s komponentom ruka veoma brojni u oba jezika, u ovom radu smo se ograničili samo na one kojima se leksikalizuju ljudske emocije.

\section{Izvori i građa, cilj i metodologija rada}

Osnovnu frazeološku bazu sa komponentom ruka u srpskom i grčkom jeziku ekscerpirali smo iz jednojezičnih rečnika opšte namene srpskog $i$ grčkog jezika. Takođe smo koristili frazeološki rečnik srpskog jezika Đorđa Otaševića, kao i frazeološki rečnik hrvatskog lingviste Josipa Matešića. Grčki jezik, na žalost, slabo raspolaže ovom vrstom posebnih rečnika, stoga smo konsultovali samo rečnike Vlahopulosa i Jordanidu. Korpus smo upotpunili građom iz dvojezičnih rečnika srpskog i grčkog jezika.

Glavno polazište našeg rada jeste uspostavljanje paralele između srpskih i grčkih frazeoloških jedinica na osnovu somatizma ruka i to kroz konceptualno polje emocija. Pre svega, osnovni cilj rada jeste da se uporede semantička značenja prikupljenih leksičkih spojeva iz korpusa, potom da se utvrde sličnosti i razlike te na osnovu dobijenih rezultata da se klasifikuju frazeologizmi na osnovu odgovarajućih konceptualnih domena kojima pripadaju. U tom pogledu se svrstavanje vrši na osnovu dva semantička polja - pozitivnog i negativnog. Neutralno semantičko polje nismo zabeležili, što je donekle sasvim očekivano, s obzirom da se putem upotrebe ovih frazeologizama (ali i ne samo njih) implicira aktivno učešće govornog lica u komunikativnom činu, njegova lična zainteresovanost kao i potreba za kakvom karakterizacijom i/ili deskripcijom činjeničnog stanja u skladu sa time kako govorno lice doživljava datu situaciju. U radu primenjujemo, pored kontrastivne i konceptualne metode i analize, i statističku metodu.

Jedan od ključnih pojmova za kontrastivnu lingvistiku i kontrastivnu analizu jeste ekvivalencija, koja se u teoriji kontrastivne analize definiše 
kao približna jednakost značenja. U njenoj osnovi leži semantički kriterijum na osnovu koga se utvrđuje komparabilnost. Ukoliko leksičke kategorije koje želimo da podvrgnemo ovom lingvističkom postupku nalazimo samo kod jednog jezika i nikad se ne javlja u prevodu drugog jezika, te leksičke kategorije nisu uporedive, stoga se komparabilnost utvrđuje na osnovu prevodne ekvivalencije (Đorđević, 2004).

Kada je reč o terminologiji upotrebljenoj u našem radu, opredelili smo se da sve frazeološke sklopove nazivamo frazeologizmima ili frazeološkim jedinicama (u daljem tekstu FJ), bez obzira na njihov strukturalni karakter kao i na sva postojeća teorijska razmatranja u vezi sa njima u brojnoj stručnoj literaturi.

Kako do sada nije bilo opsežnijih istraživanja na ovu temu², imajući na umu srpsko-grčka frazeološka istraživanja, smatramo da bi ovaj rad mogao predstavljati doprinos izučavanju kontrastivne frazeologije srpskog i grčkog jezika.

\section{Kontrastivna analiza somatizma ruka}

\subsection{O simbolici ruke}

Ruka, gornji ekstremitet kod čoveka, koji se proteže od ramena do vrhova prstiju, simbolizuje nekoliko kulturno-civilizacijskih elemenata koji su bezmalo podudarni kod svih, ili barem kod velike većine, naroda na svetu: delanje, umešnost, silu, vlast, moć, nadležnost, svojinu, zaštitu, kontrolu, junaštvo, mudrost, svedočenje, zaklinjanje, zahtev, molbu, molitvu, predaju, ali i stranu, odnosno, položaj, determiniše se vreme u odnosu na nju itd. U svojim navodima Kamings (2004) zaključuje da „ruka predstavlja aktivnu silu, prelazak sa teorije na praksu. U egipatskim hijeroglifima, ruka označava bilo koju aktivnost, kao što su rad, zaštita, kontrola itd. U kabali, desna ruka se povezuje sa nabrajanjem dobrote, a leva sa nabrajanjem junaštva. Mnogorukost bogova i boginja u hinduizmu i budizmu simbolizuje saosećajnu pomoć i različite sile i motive kosmičke prirode, kao i posebne funkcije određenog božanstva. U okviru hrišćanstva, Svetog trojstva, ruka simbolizuje Oca“" (Kamings, 2004: 295-296).

2 Koliko smo uspeli da se informišemo, postoji svega jedan rad koji kontrastivno razmatra somatizam ruka u frazeologizmima, i to:

Predrag J. Mutavdžić - Anastassios L. Kampouris. (2013). „Frazeologizmi izvedeni od lekseme ruka (manonimi) u savremenom srpskom, grčkom i rumunskom jeziku“, Anali Filološkog fakulteta, tom XXV, sveska II, Beograd: Filološki fakultet, 165-192. 
Le Gof se nadovezuje na prethodnog autora i ističe kako „ruka, kontroverzni organ, zauzima veoma važno mesto u srednjem veku odslikavajući ideologije i društvena previranja tokom ovog perioda. Ruka postaje simbol zaštite ali i naredbe. Veoma bitna, takođe, jeste božanska ruka sa neba koja upravlja čovečanstvom. Reč je o gornjem udu kojim se molimo, čin koji determiniše sveštena lica ali i hrišćane. Ovaj organ služi isto tako za gestikulaciju. Ujedno je i organ kojim kažnjavamo nekoga, ali i kojim obavljamo poslove nižeg reda poput fizičkog rada. Sen Benua beleži da je manualni/ fizički rad jedna od prvih dužnosti monaha, vid iskupljenja i poniznosti. Vazal pruža svoje ruke feudalcu (stavlja ih u njegove) kao znak potčinjenosti,

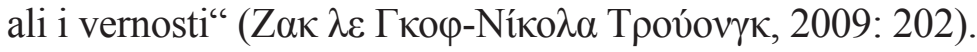

\subsection{Semantika ruke}

Pod odrednicom ruka u RMS (RMS6: 575-576) zabeleženo je deset semantičkih značenja:

1) gornji ud čovečijeg tela,

2) izvršilac kakvog posla,

3) rukopis,

4) vlast, moć, nadležnost, svojina,

5) vrsta, metod, stalež,

6) izvor, poreklo,

7) strana,

8) pristanak na brak,

9) sloboda delovanja,

10) sreća.

Isti broj semantičkih značenja odrednice $\chi \varepsilon$ Emanuila Kriarasa (Kpıарás, 1995: 1489-1490), i to:

1) gornji ekstremitet ljudskog tela,

2) deo ruke od zgloba do vrhova prstiju, šaka,

3) osoba,

4) organ kojim se obavlja neka radnja,

5) alat kojim se interveniše,

6) za izražavanje svojine,

7) odgovornosti, kontrole,

8) oznaka mesta, smera,

9) ručica alata, uređaja,

10) za izražavanje doze, kao i koliko puta se nešto radi. 
Već na osnovu ovog letimičnog upoređenja može se primetiti da su semantička značenja iste lekseme u oba jezika sasvim različita, a da u svega dva slučaja postoje iskazane podudarnosti (u srpskom značenje 1, u grčkom značenje 1 i 2; u srpskom značenje 2, u grčkom značenje 3). Polazeći od ovog zapažanja, te imajuči u vidu da frazeologizmi usled procesa metaforizacije razvijaju nova značenja, želimo da ispitamo frazeološke jedinice s komponentom ruka u pomenutim jezicima, kako bismo ustanovili da li i među njima postoje tako velike razlike ili ne.

\subsection{Somatizam ruka $u$ semantičkim poljima}

Kako smo na početku našeg rada istakli, konceptualna analiza FJ sa komponentom ruka kreće se unutar dva semantička polja, pozitivnog i negativnog.

\subsubsection{Somatizam ruka u pozitivnim semantičkim poljima}

3.3.1.1 Ruka u semantičkom polju:

ZADOVOLJSTVO, USHIĆENJE, RADOST, SREĆA

Sve zabeležene FJ koje čine ovo pojmovno polje služe za izražavanje pozitivnih ljudskih osećanja, poput sreće, radosti, zadovoljstva, euforije i slično. ${ }^{3}$

\begin{tabular}{|c|c|c|}
\hline Srpski & Grčki & Ekvivalencija \\
\hline raširenih ruku & ${ }^{*} \mu \varepsilon \alpha \alpha \chi \chi \tau \varepsilon^{\prime} \varsigma \alpha \gamma \kappa \alpha \dot{\lambda} \varepsilon \varsigma^{3}$ & nulta \\
\hline (zadovoljno) trljati ruke & $\tau \rho i \beta \omega \tau \alpha \chi \varepsilon \varepsilon^{\prime}\llcorner\alpha \mu v$ & parcijalna \\
\hline $\begin{array}{c}\text { obema rukama (davati / } \\
\text { poklanjati) }\end{array}$ & 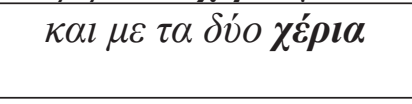 & parcijalna \\
\hline biti dobre / srećne ruke & 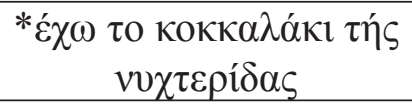 & nulta \\
\hline pozlatile ti se ruke! & 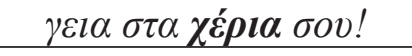 & parcijalna \\
\hline
\end{tabular}

3 Svuda u radu gde se kao prevodni ekvivalent na grčkom jeziku pojavljuje neodgovarajuća komponenta, odnosno FJ koja se izražava drugom vrstom frazeologizama, nefrazeološkim izrazom (obilikom) ili nepodudarni frazeologizam, označen je zvezdicom.

Ukoliko pak ne postoji odgovarajuća mogućnost transponovanja srpske FJ jedinice na grčki pomoću iste ili slične komponente, ili obratno, budući da za nju nismo uspeli ustanoviti grčki ili srpski ekvivalent, u polju će nužno stajati crtica. 
Frazeologizam raširenih ruku javlja se u funkciji priloške odredbe za način uz glagole dočekivati, sretati, primati i slično, što bi značilo „S radošću, prijateljski, srdačno, s dobrim raspoloženjem“. Nastao je metaforičkim prenosom značenja bazne sintagme kojom se nominira gest $^{4}$ zadovoljstva. U govornim činovima, zadovoljstvo subjekta, nosioca

$4 \quad$ Mršević-Radović u svojoj knjizi navodi da jedan broj frazeologizama nastaje semantičkom transpozicijom nefrazeološke sintagme koja opisuje (nominira) gest. Prema definicijama iz: Rječnika stranih riječi, izraza i kratica (Zagreb, 1962) gesta označava ,,pokret tijela, osobito ruku, glave, ramena, kojim se propraćuje govor, da bi se pojačao ili zamjenio izraz“; RSANU gest označava kao „pokret ruke, glave ili kojeg drugog dela tela kojim se prati i potencira govor ili se nešto izražava“; Mršević-Radović navodi da se gest definiše na dva načina ili kao pratilac govorne akcije ili kao posebno komunikativno sredstvo (Mršević-Radović, 1987:37).

Pored iznetog, Šipka je dao i tumačenje gesta Rikarda Simeona iznetog u Enciklopedijskom rječniku lingvističkih naziva kao „znak sporazumijevanja, upozorenja (gesta pristanka, značajna g.), opomene ili pak prate govor, recitaciju, glumu itd. ..." (Simeon 1969, I, 400a). Tokom komunikacije gest vrlo uspešno sâm prenosi poruku, no u pisanom kazivanju govor se može pojmiti dvojako, bilo kao nefrazeološka sintagma koja imenuje pokret tela, poput mimike (Šipka, 2001), bilo kao frazeološka sintagma koja metonimijskim putem dobija novo značenje posredstvom psihičke reakcije koju označava. Prema Šipkinim navodima, Simeon u pomenutom rečniku definiše mimiku kao „, sposobnost da se izrazom lica i pokretima očituju osjećaji, misli i volja. Mimika je imitativna kad oponaša tjelesne ili psihičke osobine drugih osoba, ili stvaralačka kad izražava duševna stanja glumljenoga lika. Glavna su sredstva mimičkoga izražavanja mišići lica, oči i usta... izražajni pokreti mišića lica, kao jedan od oblika iskazivanja ovih ili onih osjećaja - radosti, tuge i sl. Mimički pokreti vrše se obično nehotično, reflektorno. No mogu se izazvati i voljno, a to čovjeku daje mogućnost da se njima služi svjesno, u određene svrhe (mimika glumca i sl.). mimika je jedan od pomoćnih načina ljudskoga sporazumijevanja. Prateći govor, ona pomaže njegovoj izražajnosti“.

Šipka razlikuje četiri tipa frazema gestovno-mimičkog porekla:

1) refleksne ili reflektorne;

2) demonstrativne;

3) akcione ili interventne, i

4) komunikativne.

koji nastaju složenim procesom frazeologizacije za koji su opet bitna četiri faktora:

a) psihički podsticaj pokreta gesta ili mimike;

b) fizički pokret uslovljen psihičkim podsticajem;

c) nefrazeološka sintagma koja opisuje motornu aktivnost, i

d) frazem za koji je bitna simbolizacija (Šipka, 2001:42-45). 
subjektivnog stanja, može se izraziti samim gestom bez leksikalizacije koncepta zadovoljstva. Kontrastivnom analizom utvrđena je nulta evivalencija, budući da frazeologizam raširenih ruku ima svoj ekvivalent u grčkom jeziku koji ne sadrži leksemu ruka - $\mu \varepsilon \alpha v o \imath \chi \tau \varepsilon ́ \varsigma \alpha \gamma \kappa \alpha ́ \lambda \varepsilon \varsigma$ (dosl. 'sa raširenim zagrljajima') koji takođe nosi značenje ushićenja i radosti.

Frazeologizam trljati ruke označava pozitivno emocionalno stanje koje je usledilo nakon nekog uspeha, uspešno obavljene radnje te samim tim izaziva kod čoveka „zadovoljstvo, radost, sreću“, ali i implicira „,nadanje kakvom uspehu“. U rečenici obavlja funkciju predikata. Glagol se nalazi u nesvršenom glagolskom vidu i obično se javlja u prezentu. Nastao je semantičkom transpozicijom nefrazeološke sintagme koja nominira gest, odnosno metaforizacijom. U razgovoru se najčešće ovaj frazeologizam zamenjuje gestovnim pokretom koji konceptualizuje zadovoljstvo.

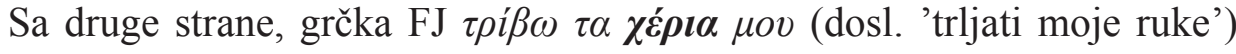
jeste samo parcijalni ekvivalent navedenog frazeologizma. Kontrastivnom analizom ustanovljena je potpuna ekvivalencija na semantičkom nivou, a parcijalna na strukturalnom, budući da se u grčkom frazeologizmu mimo glagola i imenice (zajedno s određenim članom) javlja i posesiv koji predstavlja jedinu razliku. Proces metaforizacije inspirisan je gestom trljanja ruku.

FJ obema rukama upotrebljava se uz tematski ograničen opseg verbala, poput davati, poklanjati, pomoću kojih se iskazuje koncept „zadovoljstva prilikom obavljanja samog čina“. Frazeologizam je u funkciji priloške odredbe za način. Nastao je semantičkom transpozicijom nefrazeološke sintagme koja nominira gest davanja s obe ruke, odnosno, oberučke. Stoga se ova frazeološka jedinica može razumeti i kao intenzifikator za količinu. Njegov ekvivalent u grčkom jeziku glasi $\kappa \alpha \iota \mu \varepsilon \tau \alpha \delta v ́ o$ $\chi \varepsilon ́ p ı \alpha$ (dosl. 'i sa obe ruke') i beleži podudarnost na semantičkom ali ne i na strukturnom planu. Grčki frazeologizam takođe vrši funkciju priloške odredbe načina radnje u rečenici. Utvrđena je parcijalna ekvivalencija sa morfosintaksičkim razlikama.

Frazeologizam biti dobre / srećne ruke ima značenje „,imati sreće u svemu" biti uvek srećan, odnosno biti srećan čovek. Tako je i nastao ovaj frazeologizam metaforičnim putem gde se RUKA poima kao ČOVEK. Nema svog odgovarajućeg parnjaka sa somatizmom ruka u grčkom jeziku,

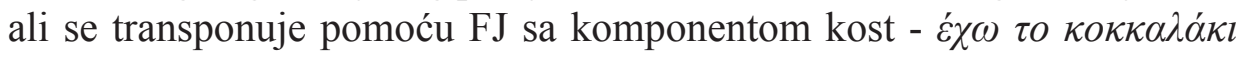




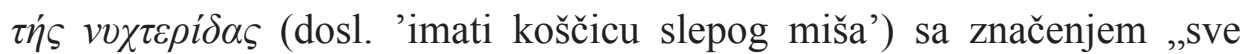
što poželim to se ostvari“. Bez obzira na morfostrukturalnu i leksičku nepodudarnost, ova dva izraza povezuje isto značenje.

Ono što smo primetili jeste da FJ pozlatile ti se ruke! ne beleži nijedan leksikografski izvor, i pored toga što se veoma često može javiti u svakodnevnim govornim činovima koji iskazuju zadovoljstvo usled neke uspešno obavljene manualne radnje (uglavnom nakon dobro skuvane kafe, skuvanog ručka itd.). Dokumentovan je, međutim, izraz u oba jezika imati

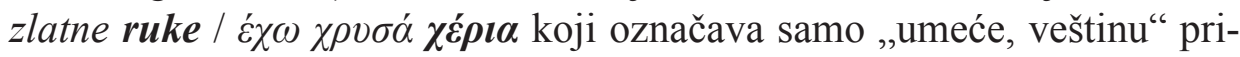
likom obavljanja nekog posla. Međutim, FJ pozlatile ti se ruke! karakteriše kolokvijalno markiran govor i, po pravilu, javlja se u formi voluntativne

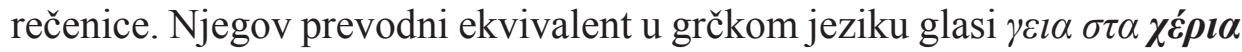
бov! (dosl. 'zdravlje tvojim rukama') i takođe leksikalizuje ,zadovoljstvo“ zbog umešno obavljene manualne radnje (npr. spremanja jela). Obe FJ nastale su metonimijskim putem gde RUKE STOJE ZA ČOVEKA, odnosno DEO ZA CELINU (Kevečeš, 2010: 172-173). U oba slučaja idiomatski izrazi se mogu zameniti odgovarajućim izrazima Živ bio! / No ' $\sigma \alpha l ~ \kappa \alpha \lambda \alpha$ ! $\mathrm{Na}$ osnovu analize utvrđena je semantička ekvivalentnost.

\subsubsection{Ruka u semantičkom polju NAKLONOST, LJUBAV, STRAST}

Sve zabeležene FJ ovog semantičkog poglavlja oslikavaju pozitivna čovekova osećanja koja se javljaju prilikom emocionalnog stanja zaljubljenosti, ljubavi, sa jedne strane, odnosno naklonosti ili poštovanja, sa druge.

\begin{tabular}{|c|c|c|}
\hline Srpski & Grčki & Ekvivalencija \\
\hline $\begin{array}{c}\text { pružiti / pružati ruku } \\
\text { (nekome) }\end{array}$ & 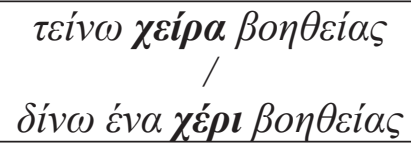 & parcijalna \\
\hline $\begin{array}{c}\text { zaprositi / zatražiti } \\
\text { (nečiju) ruku }\end{array}$ & 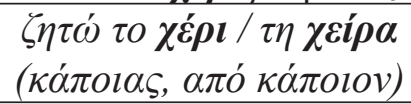 & potpuna \\
\hline $\begin{array}{c}\text { dati ruku (nekome) } \\
\text { pružiti / pružati ruku } \\
\text { (nekome) }\end{array}$ & 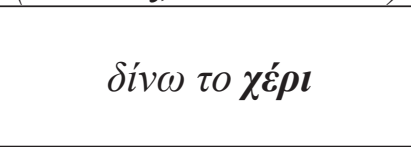 & $\begin{array}{l}\text { parcijalna } \\
\text { potpuna }\end{array}$ \\
\hline od ruke & $\left.\left(\delta \omega^{\prime} \rho o\right) \alpha \pi\right)^{\prime} \chi \varepsilon \varepsilon^{\prime}$ & nulta \\
\hline
\end{tabular}


Frazeologizam pružiti / pružati ruku (nekome) ima značenje ,pomoći nekome, pomiriti se, ponuditi nekome prijateljstvo“, znači i poštovanje prema nekome. Obavlja predikatsku funkciju u rečenici, i tvore ga kako perfektivni, tako i imperfektivni glagoli. Češće se u upotrebi javlja imperfektivni glagol i to u prošlom i budućem vremenu. Frazeologizam je nastao transponovanjem značenja pomoću metonimijski inspirisane metafore RUKA JE POMOĆ, a motivacionu bazu čini gest rukovanja kojim se izražava prijateljstvo, pomirenje, uspostavljanje dogovora i sl.

Kontrastivnom analizom utvrđena je parcijalna podudarnost između

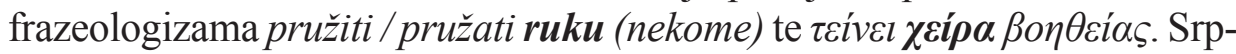
ska FJ zahteva dopunu u dativu koja ukazuje na osobu kojoj se pruža pomoć,

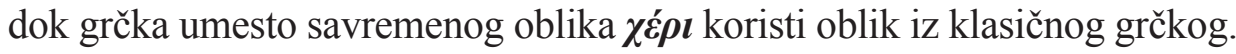

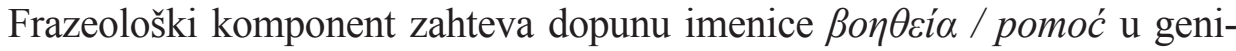
tivu, što bi doslovno u srpskom jeziku glasilo 'pruža ruku pomoći'. Grčki

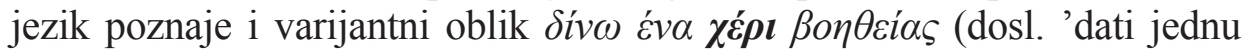

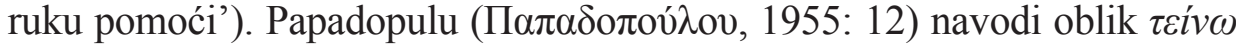

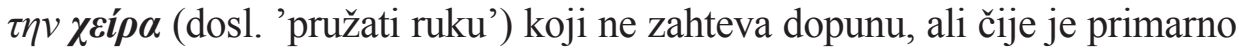
značenje „tražiti milostinju“, a sekundarno ,izmirenje, pomirenje)“.

Leksikografski izvori pod izrazom zaprositi / zatražiti (nečiju) ruku dokumentuju značenje ,ponuditi nekome brak“. Ova sema je već neko vreme marginalizovana, budući da je sâm kulturološki čin prosidbe delimično iščezao iz savremenog života Srba, pa se zato upotrebljava u izuzetno formalnim situacijama (Trivić, 2015: 317). Frazeologizam je obično u funkciji predikata rečenice, a nastao je metaforičkim putem bazne sintagme inspirisane slikom mladoženje koji traži ruku svoje buduće ne-

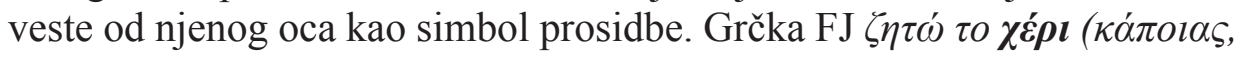

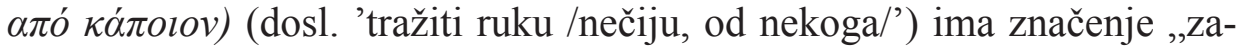

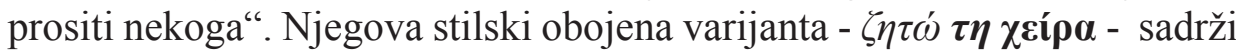
leksemu sačuvanu iz klasičnog grčkog i, po pravilu, uporebiće se samo u slučajevima kada je potrebno da se istakne visoka zvaničnost i formalnost u govoru ili pisanju. Bez obzira na jednu ili na drugu varijantu, ovaj frazeologizam jeste potpuni ekvivalent srpskom izrazu kako na semantičkom tako i na leksičkom te morfosintaksičkom planu.

Sa druge strane, FJ dati ruku (nekome) referiše samo jedno značenje

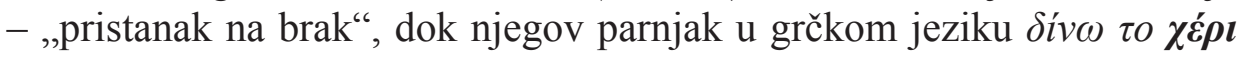
(dosl. 'dati ruku'), pored ovog značenja, beleži još i značenje pomirenja te bi u tom slučaju sasvim odgovarao srpskoj FJ pružiti ruku. Otuda 
je kod ovog frazeološkog para prisutna parcijalna ekvivalencija što zbog morfosintaksičkog neslaganja, zbog dativske rekcije u srpskom frazeologizmu, što zbog semantičke asimetrije, budući da je grčki frazeologizam polisemičan, a srpski monosemičan. Oba frazeologizma nastala su semantičkom transpozicijom osnovne sintagme koja nominira gest pružanja ruke, kao što smo objasnili na primeru frazeološke jedinice pružiti / pružati ruku (nekome), kasnije je taj čin generisao novo značenje inspirisan slikom čina prosidbe, kada mladoženja traži nevestinu ruku od njenog oca.

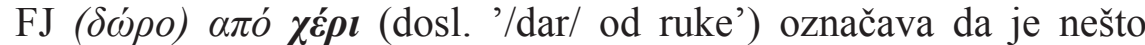
dobijeno od voljene osobe. U srpskom jeziku isto značenje bi se iskazalo identičnim frazeologizmom od ruke (u smislu ,učiniti nešto iz prijateljstva, ruke radi“"). S obzirom da ga jedino referiše RMS6 iz 1973. godine, možemo već sa sigurnošću navesti da je ovaj izraz zastareo pa zbog toga utvrđujemo odnos nulte ekvivalentnosti. Varijantni oblik ruke radi imenuje isti sadržaj, odnosno „, mali dar, poklon, kao znak pažnje prema kome“, i, kako ga takođe navodi samo RMS6, konstatujemo da je izašao iz svakodnevne upotrebe. Ove FJ nastale su istim metonimijskim putem gde se organ RUKA uzima za čitavo telo / biće, DEO STOJI ZA CELINU (Lakoff \& Jonson, 2003: 36, Kevečeš 2010: 171-174).

\subsubsection{Ruka u semantičkom polju HLADNOKRVNOST, PRISEBNOST, BEZBRIŽNOST}

Frazeološke jedinice ovog semantičkog polja izražavaju ,samokontrolu subjekta kojeg karakteriše prisebnost, snaga volje, odlučnost i smelost." Rešenost, nepokolebljivost, energičnost, odvažnost, manifestuju se kroz pasivnost, odnosno stanje mirovanja tela. , Značenje hladnokrvnosti i bezbrižnosti ponekad se graniči s čovekovom smelošću i hrabrošću, a značenje prisebnosti s opreznošću“ (Mušović, 2002: 45).

\begin{tabular}{|c|c|c|}
\hline Srpski & Grčki & Ekvivalencija \\
\hline ruka nije zadrhtala (nekome) & - & nulta \\
\hline $\begin{array}{c}\text { biti u dobrim / sigurnim ru- } \\
\text { kama } \\
\text { dolaziti / doći u prave ruke } \\
\text { položiti što u dobre ruke }\end{array}$ & $\begin{array}{c}\varepsilon i ́ \mu \alpha l \text { / } \beta \rho i \sigma \kappa o \mu \alpha l \sigma \varepsilon \\
\kappa \alpha \lambda \alpha \dot{\chi} \chi \varepsilon ́ p ı \alpha\end{array}$ & $\begin{array}{l}\text { potpuna } \\
\text { parcijalna }\end{array}$ \\
\hline
\end{tabular}


Frazeologizam ruka nije zadrhtala (nekome) javlja se u obliku i funkciji rečenice i nastao je metaforičkim putem (Mušović, 2002: 54). Glagolska rekcija FJ zahteva dativsku dopunu u funkciji logičkog subjekta. Kako smo utvrdili, ne postoji njegov adekvatni frazeološki ekvivalent u savremenom grčkom jeziku.

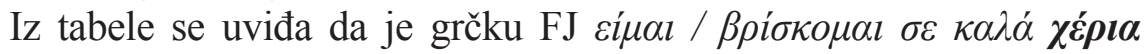
(dosl. 'biti / nalaziti se u dobrim rukama') moguće transponovati na srpski putem tri frazeologizma koja su u parasinonimijskom odnosu. Njen potpuni semantički ekvivalent jeste biti u dobrim rukama, s obzirom da verbalizuje bezbrižno stanje koje je usledilo nakon poveravanja neke osobe drugoj pouzdanoj osobi (na čuvanje, vaspitavanje, školovanje itd.) u koju se ima apsolutno poverenje. Ova FJ, koja i u srpskom i u grčkom jeziku obavlja funkciju imenskog dela predikata, nastala je na osnovu metonimije RUKE STOJE ZA ČOVEKA. U srpskom jeziku javljaju se i varijantni oblici dolaziti / doći u prave ruke te položiti što u dobre ruke identične seme, međutim različite strukture u odnosu na gore navedeni frazem, njihov prevodni ekvivalent.

\subsubsection{Ruka u semantičkom polju OLAKŠANJE}

\begin{tabular}{|c|c|c|}
\hline Srpski & Grčki & Ekvivalencija \\
\hline $\begin{array}{l}\text { *izvući se iz (nečijih) } \\
\text { šaka / šapa / kandži }\end{array}$ & 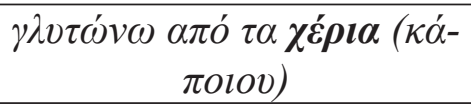 & parcijalna \\
\hline
\end{tabular}

Frazeologizam $\gamma \lambda v \tau \omega ́ v \omega$ a $\mathrm{ruku} /$ šaka /nekoga/') imenuje koncept olakšanja i smirenosti nakon ,izbegavanja nečije nadležnosti, nečijih uslova, ograničenja“. Njegov parnjak u srpskom jeziku glasi izvući se iz nečijih šaka / šapa / kandži i takođe nosi smisao „spasiti se nekoga, nečije zavisnosti“, odnosno osetiti olakšanje zbog izlaza iz date situacije. Glagol frazeologizma je svršenog glagolskog vida i obično se koristi u prošlom vremenu. Obe FJ obavljaju predikatsku funkciju. Za razliku od srpskog, u grčkom jeziku se ne pravi leksička distinkcija između ruke i šake, što će reći da u srpskom ovi somatizmi grade odnos potpune korelacije, a, kako se uočava iz primera, ova FJ se tvori pomoću različitih meronima - jednog ljudskog i dva zoonimskog porekla (šapa, kandža) - te se u tom slučaju uspostavlja parcijalna ekvivalentnost sa leksičkim i morfosintaksičkim razlikama. O načinu i poreklu frazeologizama videti poglavlje broj 5.3.1.3. 


\subsection{Somatizam ruka u semantičkim poljima sa negativnim emocijama}

\subsubsection{Ruka u semantičkom polju IGNORISANJE, INDIFERENTNOST, RAVNODUŠNOST}

Zabeležene FJ ovog tematskog polja konotiraju ljudska osećanja izazvana prilikom emocionalnog stanja indiferentnosti.

\begin{tabular}{|c|c|c|}
\hline Srpski & Grčki & Ekvivalencija \\
\hline $\begin{array}{c}\text { odmahivati / odmahnuti } \\
\text { rukom }\end{array}$ & & nulta \\
\hline $\begin{array}{l}\text { sedeti skrštenih ruku / } \\
\text { imati skrštene ruke }\end{array}$ & 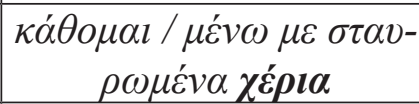 & parcijalna \\
\hline $\begin{array}{c}\text { prekrstiti / sklopiti / } \\
\text { skrstiti ruke }\end{array}$ & 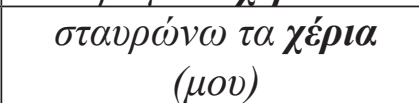 & potpuna \\
\hline $\begin{array}{c}\text { dizati / dići ruke od (nek- } \\
\text { oga, nečega) }\end{array}$ & 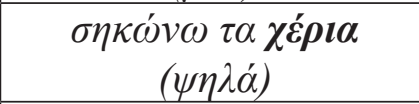 & parcijalna \\
\hline obesiti ruke & - & nulta \\
\hline
\end{tabular}

Značenje FJ odmahivati / odmahnuti rukom jeste „odbaciti nešto bez ikakvog interesa, s prezirom, biti indiferentan, ravnodušan, nezainteresovan“. U rečenici najčešće obavlja predikatsku funkciju, mada može posedovati i prilošku. Nastao je transponovanjem značenja osnovne sintagme inspirisano gestom kojim se nominira ignorancija prema nekome ili nečemu. Utvrđena je nulta ekvivalencija.

Frazeologizam sedeti skrštenih ruku ima značenje ,ne preduzimati ništa, ostajati ravnodušan“. Frazeologizam vrši funkciju priloške odredbe načina radnji vizuelnih percepcija i radnji koje izražavaju glagole stanja (npr. posmatrati, gledati, sedeti, stajati; Mušović, 2002: 85). Javlja se i varijantni oblik imati skrštene ruke sa istim značenjem. Frazeologizam je nastao slikovnom shemom gesta kojim se nominira pasivnost, inert-

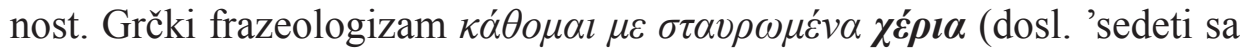

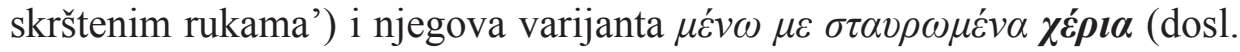
'ostati sa skrštenim rukama') imaju isto značenje - „,biti neaktivan; sedeti i ne raditi ništa“. Međutim, konotativno značenje upućuje na pasivnost i inertnost. Analizom smo utvrdili semantičku ekvivalenciju grčkog i 
srpskog frazeologizma, odnosno parcijalnu ekvivalenciju sa leksičkim i morfosintaksičkim razlikama. Kako je nastao procesom metaforizacije, budući motivisan takođe gestom, njegova je funkcija predikatska, pošto podrazumeva upotrebu glagola stanja (sedeti, ostati) kao i predloga $\mu \varepsilon /$ sa, koji zahteva sintagmu u akuzativu. Na strukturalnom planu utvrđena je parcijalna ekvivalencija.

Frazeologizam prekrstiti / sklopiti / skrstiti ruke ima isto značenje kao i gore navedena FJ koja vrši predikatsku funkciju u rečenici. Glagolski komponenti su perfektivni i obično se upotrebljavaju u prošlom vremenu. Ima svoj ekvivalent sa istom predikatskom funkcijom u grčkom $\sigma \tau \alpha v \rho \omega ́ v \omega$

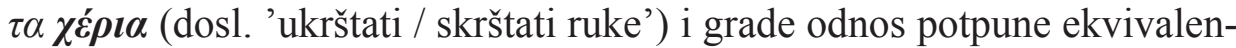
cije. Način motivacije i nastanka je isti.

Dizati / dići ruke (od nekoga / nečega) označava „napustiti nekoga kao nepopravljivog“ kao beznadežan slučaj, „manuti se uzaludnog posla“. Frazeologizam je u funkciji predikata, glagol se obično koristi u prošlom vremenu, zahteva dopunu u genitivu sa predlogom „od“ koja označava nezainteresovanost za određenu osobu ili predmet. Reč je o još jednom gestovno-mimičkom frazeologizmu.

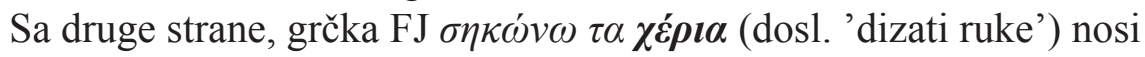
smisao prekidanja svih pokušaja, odustajanja, gubljenja interesovanja i nalazi se u funkciji predikata. Utvrđena je parcijalna ekvivalencija sa srpskim parnjakom, budući da grčki frazeologizam ne zahteva gladolsku rekciju koja označava predmet nezainteresovanosti. Dodatno, javlja se i

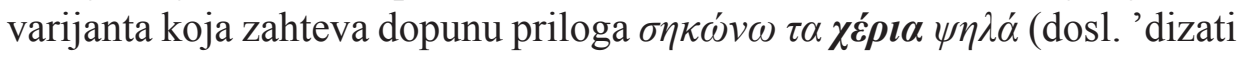
ruke visoko') i u tom slučaju u pitanju je leksička nepodudarnost kojom se postiže markiranost samog čina.

Frazeologizam obesiti ruke „ne raditi ništa, besposličariti“ imenuje koncept indiferentnosti, letargičnosti i obavlja predikatsku funkciju. Glagol je perfektivan i upotrebljava se u prošlom vremenu. I ovaj frazeologizam pripada velikoj grupi gestovnih frazeologizama i, kako smo utvrdili, nema svog parnjaka u ciljnom jeziku.

\subsubsection{Ruka u semantičkom polju}

NEDOUMICA, ČUĐENJE, ZBUNJENOST, IZBEZUMLJENOST

Uočene FJ ovog semantičkog polja oslikavaju emocionalna stanja ljudi usled kakvog bilo pozitivnog ili negativnog događaja, situacije, van 
očekivanja, iznenadni događaj uzrokuju nedoumicu, čuđenje, zbunjenost i izbezumljenost.

\begin{tabular}{|c|c|c|}
\hline Srpski & Grčki & Ekvivalencija \\
\hline $\begin{array}{c}\text { krstiti / prekrstiti se levom ru- } \\
\text { kom / i levom i desnom rukom }\end{array}$ & - & nulta \\
\hline širiti ruke & - & nulta \\
\hline
\end{tabular}

Frazeologizam krstiti / prekrstiti se levom rukom / i levom i desnom rukom izražava „duboko čuđenje“, a u rečenici ima predikatsku funkciju. Po svemu sudeći, sasvim je specifičan za srpski jezički areal, pošto njegova ,ekspresivnost povećava apsolutnu neprirodnost i neprihvatljivost radnje koja se njime označava" (Mušović, 2002: 95). Zbog toga je utvrđen nulti stepen ekvivalencije. Bezmalo isto se može reći i za FJ širiti ruke koja takođe nema svog ekvivalenta u grčkom i koja označava „,̌uđenje i izražavanje nedoumice“. I ona se javlja u rečenici u funkciji predikata.

3.4.3. Ruka u semantičkom polju NEMORALNOST, NEČASNOST

\begin{tabular}{|c|c|c|}
\hline Srpski & Grčki & Ekvivalencija \\
\hline $\begin{array}{c}\text { (u)prljati / (o)kaljati } \\
\text { ruke (čime) }\end{array}$ & 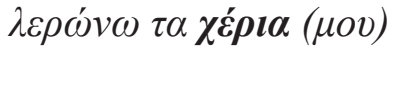 & parcijalna \\
\hline imati prljave ruke & 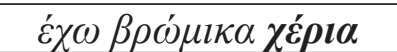 & potpuna \\
\hline
\end{tabular}

Frazeologizam prljati (uprljati, kaljati, okaljati) ruke i njegov grčki

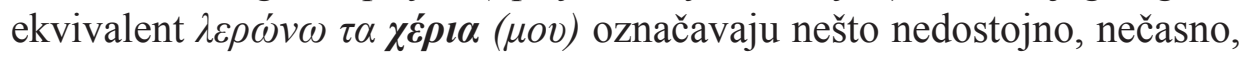
protivzakonito, odnosno „mešati se u nepošten posao“. Frazeologizam je obično u funkciji predikata. Negacija se može javiti uz glagol. Srpski frazeologizam zahteva dopunu u instrumentalu kojim se označava objekat prezira (Mušović, 2002: 112), dok grčki zahteva posesiv koji ukazuje na osobu koja čini kakav prekršaj. Ovaj frazeološki par je u odnosu parcijalne ekvivalencije sa morfo-sintaktičkim razlikama.

U oba jezika smo uočili i njihove frazeološke parnjake - imati prl-

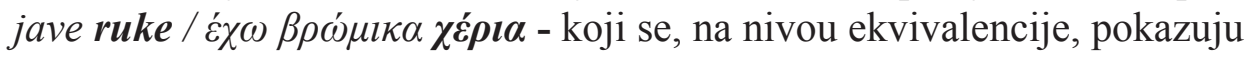
kao sasvim podudarni i semantički i morfosintaktički. 
3.4.4. Ruka u semantičkom polju UZRUJANOST, UZNEMIRENOST, ZABRINUTOST

\begin{tabular}{|c|c|c|}
\hline Srpski & Grčki & Ekvivalencija \\
\hline $\begin{array}{c}\text { kršiti / lomiti /stiskati } \\
\text { ruke/prste }\end{array}$ & $\sigma \pi \alpha \dot{\alpha} \omega$ & nulta \\
\hline
\end{tabular}

Frazeologizmom kršiti (lomiti, stiskati) ruke / prste opisuje se neposredno uočeno činjeničko stanje koje je proizvod situacije u kojoj se govorno lice zateklo te se njime plastično dočarava (označava) nespokojna, zabrinuta ili uznemirena osoba. Frazeologizam može imati funkciju predikata u rečenici, ali ukoliko se upotrebljava u formi priloga može imati i prilošku funkciju. Nastao je metaforičkim putem inspirisan refleksivnim gestom kršenja prstiju, iniciran navedenim emocionalnim stanjem uznemirenosti, uzrujanosti, zabrinutosti itd. U grčkom jeziku njegov je parnjak $\sigma \pi \alpha \dot{\alpha} \omega \tau \alpha \delta \dot{\alpha} \chi \tau v \lambda \dot{\alpha}(\mu o v)$ (dosl. 'lomiti svoje prste') no beležimo nultu ekvivalenciju.

\subsubsection{Ruka u semantičkom polju NEMOĆ, OČAJ}

Frazeološke jedinice ovog semantičkog polja služe za izražavanje emocionalnog stanja očaja namerno izazvanog usled prisile ili usled spleta okolnosti koje dovode subjekat u bezizlaznu situaciju ili bespomocan položaj.

\begin{tabular}{|c|c|c|}
\hline Srpski & Grčki & Ekvivalencija \\
\hline $\begin{array}{c}\text { vezati ruke (nekome) } \\
\text { / } \\
\text { vezati } \underline{\text { ruke i noge }} \\
\text { (nekome) }\end{array}$ & 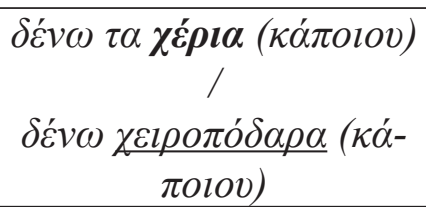 & parcijalna \\
\hline $\begin{array}{c}\text { dizati / dići ruke } \\
\text { od (nekoga, nečega) }\end{array}$ & $\begin{array}{c}\sigma \eta \kappa \omega ́ v \omega \tau \alpha \chi \varepsilon \dot{\rho} \rho t \\
(\psi \eta \lambda \dot{\alpha})\end{array}$ & parcijalna \\
\hline dići ruku na sebe & - & nulta \\
\hline $\begin{array}{c}\text { biti odsečenih ruku / } \\
\text { odsečene su (nekome) } \\
\text { ruke }\end{array}$ & 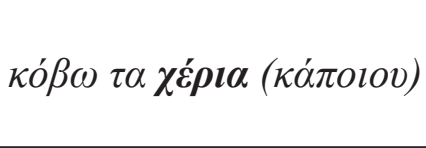 & parcijalna \\
\hline imati samo dve ruke & 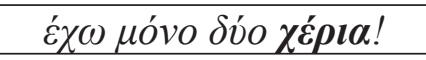 & potpuna \\
\hline
\end{tabular}


Značenje frazeologizma vezati ruke (nekome) jeste „sprečavati nekoga u čemu oduzimajući mu slobodu u postupcima“, u funkciji je predikata i zahteva dativsku rekciju glagola koja označava osobu koja je sprečena u obavljanju kakvog posla, dužnosti. Takođe je dokumentovana i njegova varijanta vezati i ruke $i$ noge (nekome) koja dodatno ističe i naglašava apsolutnu nemoć i sprečenost, odnosno nemogućnost da se išta preduzme ili učini. Ovom FJ se postiže viši stepen emfaze u iskazu i slikovitiji prikaz. Frazeologizam biti vezanih ruku sadrži značenje ,biti zavisan od nekoga, nemati slobodu odlučivanja, biti ograničen u raspolaganju nečim“.

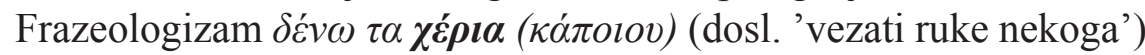
vrši funkciju predikata u rečenici i zahteva dopunu posesivnog genitiva koji označava osobu čije se ruke vezuju i koja nije u mogućnosti da deluje. Frazeologizam je nastao procesom metaforizacije inspirisane slikom osobe koja ima zavezane ruke. Kontrastivnom analizom utvrđena je parci-

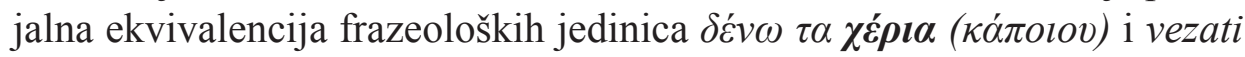
ruke (nekome) sa morfološkim razlikama. Kod frazeološkog para $\delta \varepsilon ́ v \omega$

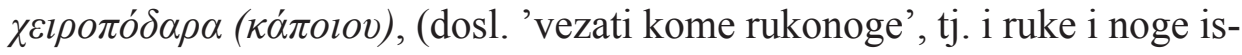
tovremeno) vezati ruke i noge (nekome) uočavamo postojanje parcijalnog poklapanja takođe sa morfološkim razlikama.

Frazeologizam dizati / dići ruke od (nekoga, nečega) već smo naveli i analizirali u tački 3.4.1. Nastao je metaforičkim putem, motivisan životnom tematikom majstora koji ukoliko prilikom obavljanja posla nailaze na poteškoće odlažu posao (Mušović, 2002: 253). Dok FJ $\sigma \eta \kappa \omega ́ v \omega$

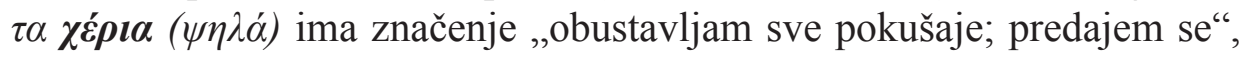

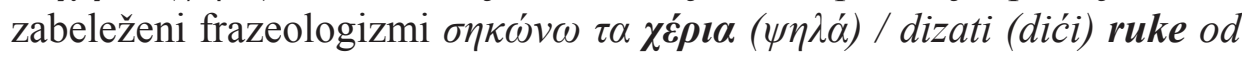
(nekoga, nečega) su primeri potpune semantičke, ali parcijalne strukturalne ekvivalencije.

Frazeologizam dići ruku na sebe označava pokušaj samoubistva, uglavnom vrši predikatsku funkciju u rečenici i nastao je metaforičkim putem. Kako u grčkom jeziku ne poseduje svoj adekvatni prevodni ekvivalent, utvrđen je nulti stepen ekvivalencije.

Frazeologizam biti odsečenih ruku pripada domenu sputanosti zbog „nemanja slobode u određenim postupcima, odnosno, u radu“. Glagolski komponent se uglavnom javlja u sadašnjem vremenu. Varijanta odsečene su (nekome) ruke referiše isti domen i zahteva dativsku rekciju koja denotira osobu koju nešto u nečemu sputava. Frazeologizmi imaju funk- 
ciju imenskog dela predikata. Inspirisani su slikom osobe kojoj su ruke odsečene (kako su se često u srednjem veku ljudi kažnjavali za prekršaje

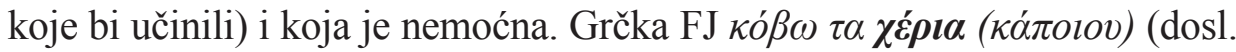
'seći ruke /nekoga/') jeste polisemična i pripada kako domenu nemoći zbog nametnutih raznih prepreka, često i sabotaže, tako i domenu pretnje kojoj će uslediti navedena kazna. Za razliku od srpske, poseduju funkciju predikata u rečenici. Nastala je i motivisana je na isti način kao njegov srpski parnjak. Na semantičkom nivou uspostavljaju odnos parcijalne ekvivalencije.

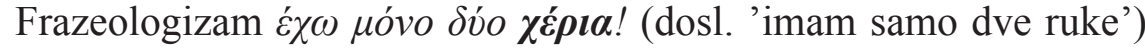
imenuje koncept nemoći usled nemogućnosti da se više radnji istovremeno odrade. Obavlja predikatsku funkciju u rečenici, a glagol se uglavnom upotrebljava u sadašnjem vremenu. I pored toga što u srpskim leksikografskim izvorima ne pronalazimo frazeologizam slične sadržine, u kolokvijalnoj komunikaciji se može čuti izraz imam samo dve ruke! sa istim značenjem. Stoga, ovaj frazeološki par gradi odnos potpune ekvivalencije.

3.4.6. Ruka u semantičkom polju

DODVORAVANJE, PONIZNOST, POKORNOST

\begin{tabular}{|c|c|c|}
\hline Srpski & Grčki & Ekvivalencija \\
\hline $\begin{array}{c}\text { biti slepo oruđe u (nečijim) } \\
\text { rukama }\end{array}$ & - & nulta \\
\hline jesti (nekome) iz ruke & 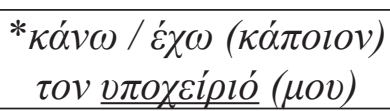 & nulta \\
\hline 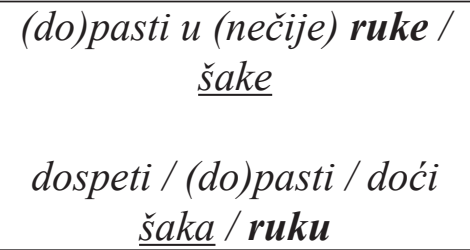 & $\begin{array}{c}\pi \varepsilon \dot{\varepsilon} \varphi \tau \omega \sigma \tau \alpha \chi \bar{\varepsilon} \rho ı \alpha\left(\kappa \alpha^{-}\right. \\
\pi o l o v)\end{array}$ & $\begin{array}{l}\text { potpuna } \\
\text { parcijalna }\end{array}$ \\
\hline $\begin{array}{l}\text { biti / ležati / nalaziti se u } \\
\text { (nečijim) rukama /šakama }\end{array}$ & $\begin{array}{c}\pi \varepsilon \dot{\varepsilon} \varphi \tau \omega \sigma \tau \alpha \chi \bar{\varepsilon} \rho ı \boldsymbol{\alpha}\left(\kappa \alpha^{-}\right. \\
\pi \text { olov) }\end{array}$ & parcijalna \\
\hline
\end{tabular}

Frazeologizam biti slepo oruđe u (nečijim) rukama imenuje sledeći koncept: „biti pokorni izvršilac tuđih želja, tuđe volje, biti sredstvo za ostvarenje tuđeg cilja“. Obavlja funkciju imenskog dela predikata. Nastao je metaforičkim putem baziran na ontološkoj metafori ORUĐE/PREDMET JE ČOVEK. Ustanovljen je odnos nulte ekvivalencije. 
Frazeologizam jesti (nekome) iz ruke (= „biti pokoran“) markiran je i izuzetno negativno obojen. Obavlja predikatsku funkciju u rečenici. Glagolski komponent izraza je dvovidski i obično se javlja u sadašnjem vremenu. Kako smo pretraživanjem izvora u grčkom jeziku ustanovili da ne postoji njegov adekvatan semantički i strukturalni ekvivalent, mišljenja smo da bi ovoj srpskoj FJ mogla donekle odgovarati grčka $\kappa \alpha ́ v \omega / \varepsilon^{\prime} \chi \omega$

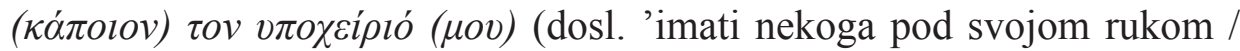
učiniti nekoga svojim potčinjenim / poslušnikom'). Ovaj frazeološki izraz se na strukturalnom (tačnije rečeno, mofrološkom) planu unekoliko

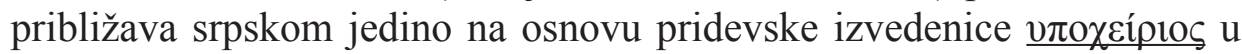
kojoj se prepoznaje stara grčka imenička osnova reči ruka ( $\chi \varepsilon i ́ p)$.

Frazeologizam (do)pasti u (nečije) ruke / šake ima značenje ,postati nečija svojina, posed“", pa samim tim označava nečiju potčinjenost. Izraz

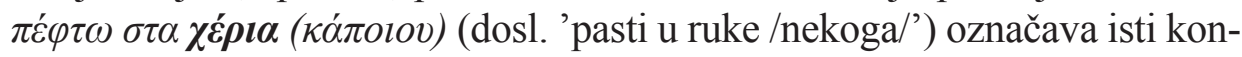
cept i, zajedno sa svojim parnjakom, grade odnos potpune ekvivalencije, imajući na umu, kako smo naznačili, da leksema $\chi \dot{\varepsilon} \rho \iota$ semantički pokriva dve jasno odvojene konceptualne celine u srpskom, i ruku i šaku. Nastali su sematničkom transpozicijom bazne sintagme, metaforičkim putem, sa polaznom pojmovnom metaforom da je RUKA JE POSUDA / SADRŽATELJ. Otuda se PONIZNOST konceptualizuje kao POSEDOVANJE.

Sa druge strane, u srpskom jeziku se zapaža i frazeološki obrt dospeti / (do)pasti / doći šaka / ruku koja označava relativno isti sadržaj samo nešto drugačije strukture i zato gradi odnos parcijalne ekvivalencije zbog nešto izmenjene morfologije. U jednom užem kontekstu, FJ dopasti šaka označava i otvoreno ispoljavanje pretnje prema nekome (=,dohvatiti / dočepati koga“) te $\mathrm{u}$ tom pogledu sasvim korespondira na semantičkom, ali ne i na struk-

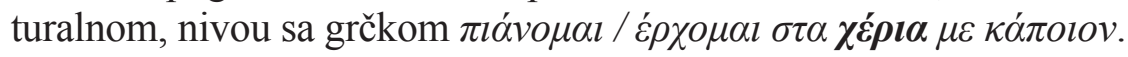

Frazeološki izraz biti / ležati / nalaziti se u (nečijim) rukama /

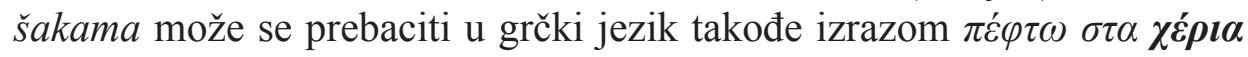

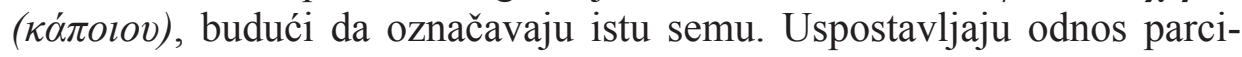
jalne ekvivalencija sa leksičkim razlikama.

3.4.7. Ruka u semantičkom polju POTIŠTENOST, PATNJA, TUGA, NESREĆA

\begin{tabular}{|c|c|c|}
\hline Srpski & Grčki & Ekvivalencija \\
\hline biti zle / nesrećne ruke & 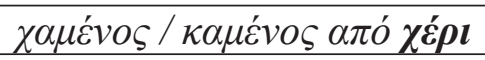 & $\mathrm{p}$ \\
\hline
\end{tabular}


Frazeologizam biti zle / nesrećne ruke predstavlja antipod frazeološkog izraza biti dobre/srećne ruke i označava baksuznu osobu koja nikada nema sreće. Obavlja funkciju imenskog dela predikata, a glagol se

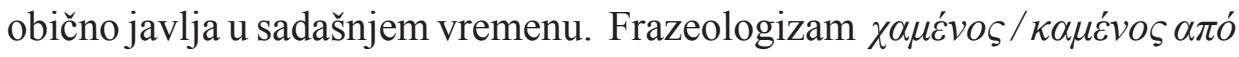
$\chi \varepsilon ́ p \boldsymbol{c}$ (dosl. 'izgubljen od ruke') konceptualizuje siguran neuspeh, imenuje poduhvat koji je osuđen na neuspeh. Iako se na semantičkom polju ove dve FJ podudaraju, njihova se struktura, međutim, razlikuje. O načinu njihovog nastanka i motivaciji više je rečno u tački 5.3.1.1.

3.4.8. Ruka u semantičkom polju OPOMENA, UPOZORENJE, PRETNJA

\begin{tabular}{|c|c|c|}
\hline Srpski & Grčki & Ekvivalencija \\
\hline $\begin{array}{c}\text { dalje ruke od (koga) / } \\
\text { ruke (k) sebi! } \\
\text { miči / sklanjaj ruke od } \\
\text { (nekoga, nečega)! }\end{array}$ & 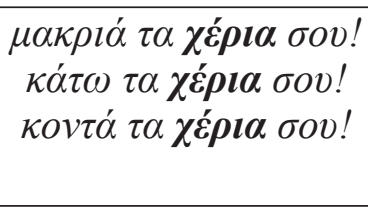 & parcijalna \\
\hline ruke uvis! / ruke gore! & 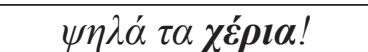 & potpuna \\
\hline $\begin{array}{l}\text { prste ću ti iseći! I } \\
\text { ruke ću ti odseći! }\end{array}$ & 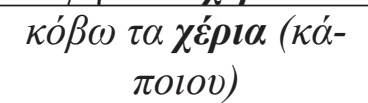 & $\begin{array}{c}\text { nulta } \\
\text { parcijalna }\end{array}$ \\
\hline
\end{tabular}

Frazeološki niz dalje ruke od, (k) sebi ruke, miči (sklanjaj) ruke od (nekoga, nečega)! karakterističan je za govorni čin upozorenja sa značenjem „ostavi to, to nije tvoje“. Ne mešaj se, ne diraj tuđe stvari inače će uslediti kazna za takvo ponašanje. Frazeologizmi se uvek javljaju u formi zapovednog načina. Frazeologizmi dalje ruke od i miči (sklanjaj) ruke od (nekoga, nečega) zahtevaju predloško padežnu dopunu, predloga od koji kongruira sa partitivnim genitivom. Način nastanka je metonimijski gde se RUKA konceptualizuje kao OSOBA / ČOVEK, što bi značilo „kloni se ti nečega“.

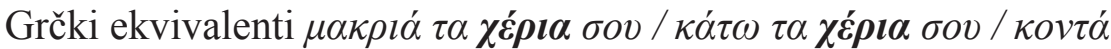

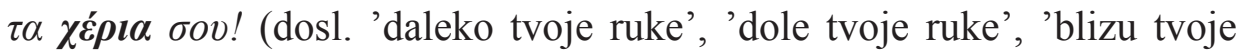
ruke') su po svojoj strukturi eliptične rečenične konstrukcije čiji je smisao da označe naredbu „ne pružaj ruke ka meni“, „drži se podalje od mene“. Način nastanka i motivisanosti su isti kao i kod srpskog frazeologizma. Uspostavljaju odnos parcijalne ekvivalencije na nivou strukture. 
Gestovni izraz ruke uvis! ili varijantni oblik ruke gore! koji je još

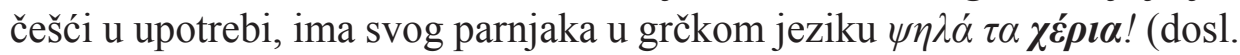
'visoko ruke') strukturalno istovetne konstrukcije. Karakteristični su za govorni čin naredbe, stoga se javljaju u formi zapovedne rečenice. Koriste se uglavnom prilikom hapšenja, ali i kao upozorenje pritivniku da se ne pomera i ne dodiruje ništa kako bi ga imobilisali. Nastali su semantičkom transpozicijom bazne sintagme koja nominira gest podizanja ruku koji se negativno konotira. Pojmovna metafora glasi PODIGNUTE RUKE SU PREDAJA. Frazeologizme možemo odrediti kao apsolutne ekvivalente.

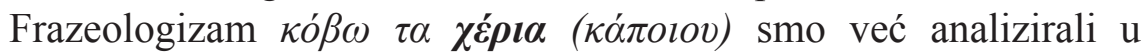
tački 5.4.5 te, pored ukazanih značenja, on poseduje, u jednom užem semantičkom polju, i koncept otvorene pretnje, što bi bilo odgovarajuće sa srpskom FJ prste / ruke ću ti odseći / iseći koji zahteva dativsku rekciju, za razliku od grčkog somatizma koji zahteva dopunu u genitivu. U zavisnosti od somatizma koji učestvuje u građenju FJ možemo govoriti o parcijalnoj, ali i o nultoj ekvivalenciji.

3.4.9. Ruka u semantičkom polju RAZDRAŽENOST, SRDŽBA, BES

\begin{tabular}{|c|c|c|}
\hline Srpski & Grčki & Ekvivalencija \\
\hline $\begin{array}{c}\text { dospeti / (do)pasti / doći } \\
\text { (čijih) šaka / ruku } \\
\text { dospeti / (do)pasti / doći u } \\
\text { (čije) šake / ruke } \\
\text { doći do (čijih) šaka / } \\
\text { pesnica }\end{array}$ & 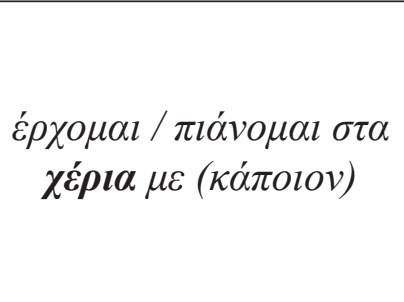 & parcijalna \\
\hline $\begin{array}{c}\text { propustiti (koga) kroz } \\
\underline{\text { sake / ruke }}\end{array}$ & - & \\
\hline dići ruku na (nekoga) & 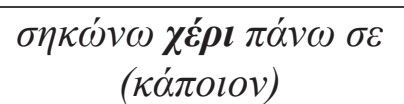 & potpuna \\
\hline
\end{tabular}

Frazeološki niz dospeti / (do)pasti / (doći) u (čije) ruke / šske; dospeti / (do)pasti / doći (čijih) šaka / ruku; doći do (čijih) šaka / pesnica procesom metaforizacije širi svoje značenje i na domen besa. Inspirisan je 
slikovnom shemom čina fizičkog obračuna. Leksikalizuje značenje „dobiti batine, biti premlaćen“. Ove FJ karakteriše izuzetna ekspresivnost i markiranost kao i neformalan, kolokvijalan stil. Svi verbali se nalaze u svršenom glagolskom vidu i upotrebljavaju se obično u prošlom i budućem vremenu. Funkcija izraza je predikatska.

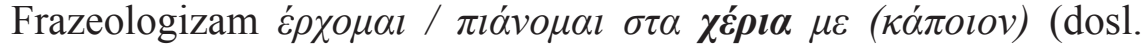
'dolaziti / hvatati se u šake / ruke') ima značenje ,svađati se, hvatati se u koštac sa nekim“. Pripada domenu razdraženosti i besa, koji dovode ne samo do verbalnog sukoba dve osobe, već i do njihovog fizičkog kontakta. Glagol FJ zahteva predloško-padežnu dopunu, predloga $\mu \varepsilon / s a$ i akuzativa koji ukazuju na osobu sa kojom se započinje sukob. Ova FJ uspostavlja odnos parcijalne podudarnosti sa leksičkomorfološkim razlikama sa čitavim frazeološkim nizom gore navedenim. Često se u upotrebi javlja u srpskom i varijanta propustiti (koga) kroz šake / ruke čiji bi prevodni ekvivalent

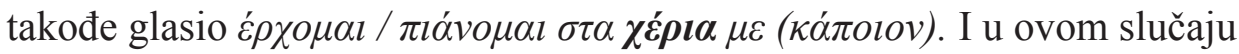
možemo govoriti o parcijalnoj ekvivalenciji. Kako smo već istakli, a što se vidi i u svim registrovanim srpskim FJ, ruke i šake se nalaze u parasinonimijskom odnosu, što znači da ne postoji bitnija promena u njihovom sadržaju i semantičkom značenju. Opredeljenje da li će se upotrebiti jedan ili drugi somatizam zavisi, pre svega, od stava govornog lica, od same situacije kao i od njegovog afektivnog raspoloženja (činjenica je da šake ipak poseduju daleko izraženiji semantički smisao i da ostavljaju jači psihološki uticaj u odnosu na ruke, s obzirom da se fizički obračun realizuje upravo meronimom šake, a ne holonimom ruke).

Frazeologizam dići ruku na (nekoga) poseduje značenje ,udariti nekoga, napasti, ubiti nekoga“. Glagol se javlja obično u prošlom vremenu. Frazeologizam ima predikatsku funkciju u rečenici. Inspirisan je gestom dizanja ruke prilikom napada na nekoga. Njegov ekvivalent u

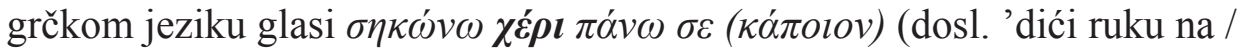
nekoga/') i označava isti koncept. Zahteva akuzativsku rekciju baš kao i srpski frazeologizam. Način motivacije je isti tako da beležimo potpunu podudarnost na svim poljima.

U sledećim tabelama dajemo zbirni pregled svih analiziranih semantičkih polja u oba jezika: 
FRAZEOLOŠKE JEDINICE SA KOMPONENTOM RUKA U SRPSKOM I GRČKOM JEZIKU

Tabela 1

\begin{tabular}{|c|c|c|}
\hline \multicolumn{3}{|l|}{ Semantička polja sa pozitivnim emocijama } \\
\hline Semantička polja & srpski & grčki \\
\hline ZADOVOLJSTVO, USHIĆENJE, RADOST, SREĆA & 4 & 3 \\
\hline NAKLONOST, LJUBAV, STRAST & 4 & 4 \\
\hline HLADNOKRVNOST, PRISEBNOST, BEZBRIŽNOST & 4 & 1 \\
\hline OLAKŠANJE, SMIRENOST & $\mathbf{0}$ & 1 \\
\hline
\end{tabular}

Tabela 2

\begin{tabular}{|l|c|c|}
\hline \multicolumn{3}{|c|}{ Semantička polja sa negativnim emocijama } \\
\hline \multicolumn{1}{|c|}{ Semantička polja } & srpski & grčki \\
\hline $\begin{array}{l}\text { IGNORISANJE, INDIFERENTNOST, } \\
\text { RAVNODUŠNOST }\end{array}$ & $\mathbf{5}$ & $\mathbf{3}$ \\
\hline $\begin{array}{l}\text { NEDOUMICA, ČUĐENJE, ZBUNJENOST, } \\
\text { IZBEZUMLJENOST; }\end{array}$ & $\mathbf{2}$ & $\mathbf{0}$ \\
\hline NEMORALNOST, NEČASNOST; & $\mathbf{2}$ & $\mathbf{2}$ \\
\hline UZRUJANOST, UZNEMIRENOST, ZABRINUTOST & $\mathbf{1}$ & $\mathbf{0}$ \\
\hline NEMOĆ, OČAJ & $\mathbf{6}$ & $\mathbf{5}$ \\
\hline DODVORAVANJE, PONIZNOST, POKORNOST & $\mathbf{4}$ & $\mathbf{2}$ \\
\hline POTIŠTENOST, PATNJA, TUGA, NESREĆA & $\mathbf{1}$ & $\mathbf{1}$ \\
\hline OPOMENA, UPOZORENJE, PRETNJA & $\mathbf{5}$ & $\mathbf{5}$ \\
\hline RAZDRAŽENOST, SRDŽBA, BES & $\mathbf{2}$ & $\mathbf{2}$ \\
\hline
\end{tabular}

\section{Zaključak}

Frazeologizmi gestovnog porekla motivisani pokretom gornjeg ekstremiteta ostvaruju različita prenesena značenja, pozitivne i negativne konotacije i to u sledećim semantičkim poljima: a) zadovoljstvo, ushićenje, radost, sreća; b) naklonost, ljubav, strast; c) hladnokrvnost, prisebnost, bezbrižnost; d) olakšanje; e) ignorisanje, indiferentnost, ravnodušnost; f) nedoumica, čuđenje, zbunjenost, izbezumljenost; g) nemoralnost, nečasnost; h) uzrujanost, uznemirenost, zabrinutost; i) nemoć, očaj; j) dodvoravanje, poniznost, pokornost; k) potištenost, patnja, tuga, nesreća; 1) opomena, upozorenje, pretnja; m) razdraženost, srdžba, bes.

U analizi frazeoloških jedinica koje podvodimo pod semantička polja emocionalnog stanja, beležimo više frazeoloških jedinica u srpskom 
jeziku nego u grčkom, što opravdava i sama semantika ove lekseme u kontrastiranim jezicima budući da leksema ruka beleži više apstraktnih značenja u odnosu na leksemu $\chi \dot{\varepsilon} \rho \imath$ u grčkom jeziku. Na osnovu gore dokumentovanih značenja zapažamo da leksema $\chi \dot{\varepsilon} \rho \imath$ u savremenom grčkom jeziku označava dve zasebne telesne celine, kako pojam ruke, kao jedan širi segment (holonim), tako i pojam šake, kao uži (meronim). U srpskom su samo u pojedinim FJ obe lekseme semantički izjednačene. Isto tako, bilo je očekivano da somatizam ruka u oba jezika u najvećem broju generiše FJ koje bi imenovale kakav manualni rad, pomaganje, silu, vlastištvo, kontro$l u$; kvalifikovale ljudske osobine $i$ sposobnosti; imenovale prostorne $i$ vremenske odnose itd., budući da označava ljudski najvažniji organ, odnosno ud, koji služi za rad. Shodno svim rezultatima naše analize, leksema ruka u oba jezika tvori znatno manji broj FJ čije je značenje apstraktno, kao i da u srpskom jeziku tvori više FJ iz konceptualnog domena emocija nego što je to slučaj u grčkom.

$\mathrm{Na}$ osnovu sprovedene analize možemo zaključiti da srpski jezik, koji pomoću komponente ruka generiše $91 \mathrm{FJ}$, tvori 40 FJ koje imenuju neku emociju, dok grčki jezik od ukupno 81 FJ tvori 29 FJ u semantičkom polju emocija. Statistički posmatrano, srpski jezik beleži veću frazemotvornu aktivnost za gotovo $11 \%$, a što se tiče FJ sa značenjem emocija čak za $27,5 \%$. Takođe je primećeno da u oba jezika prednjače oni izrazi koji imenuju negativno markirane emocije, čak 70\% u srpskom jeziku, a u grčkom 68,9\%.

$\mathrm{Na}$ osnovu izvršene analize i kontrastivnog razmatranja frazeologizama u oba jezika, uočili smo tri naredna tipa ekvivalencije:

1) potpuna ekvivalencija: podrazumeva apsolutno podudaranje na leksičkom, morfosintaksičkom i semantičkom planu;

2) parcijalna ekvivalencija: podrazumeva delimično podudaranje, primetna su neznatna odstupanja na leksičkom, i/ili morfosintaksičkom, i/ ili semantičkom planu;

3) nulta ekvivalencija: za određeni broj frazeologizama nismo pronašli odgovarajuće ekvivalente.

Najveći broj FJ uspostavlja odnos parcijalne ekvivalencije, gotovo $47,5 \%$, a nulta je zastupljena u nešto manjem iznosu (32,5\%). Kad imamo na umu stepen potpune semantičke ekivalencije između srpskog i grčkog jezika, on se ispoljava kao statistički najmanje pristutan - reč je o $20 \%$. U tom pogledu se može izvući zaključak da srpske i grčke FJ sa kom- 
ponentom ruka nisu kompatibilne između sebe onoliko koliko smo pretpostavili da bi moglo biti, ali postoji više sličnosti, nego razlika i parcijalnih nepodudaranja.

Sve ovo nedvosmisleno govori u prilog tome da je svaki narod razvio svoj vlastiti pogled na svet i da preko njega izražava svoja viđenja i percepcije. Bez obzira na bliskost i upućenost različitih naroda jednih na druge, kakav je slučaj Srba i Grka, kao i na njihov zajednički viševekovni suživot na istom geografskom prostoru, poput balkanskog, stvaranje FJ čvrsto pripada individualnoj sferi svakog naroda, a uticaji koji su se osećali (pa i danas se osećaju) ipak nemaju presudnu ulogu u njihovom građenju koliko pre u njihovom prenošenju i kalkiranju.

\section{Rečnici}

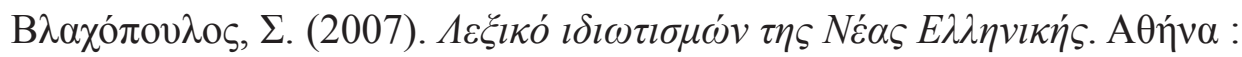

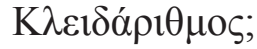

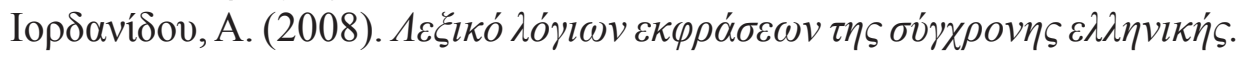

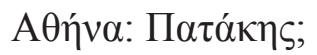

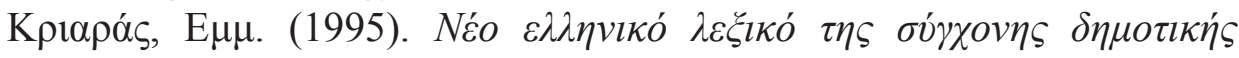

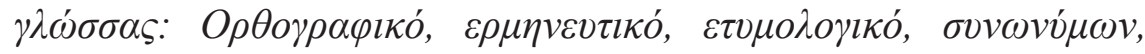

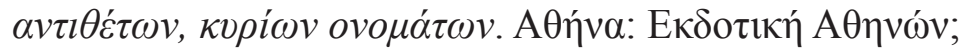

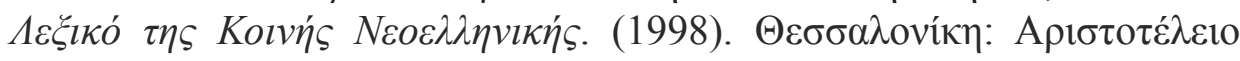

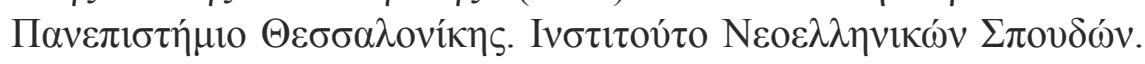

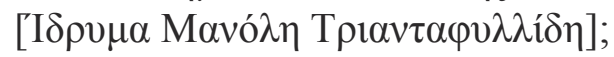

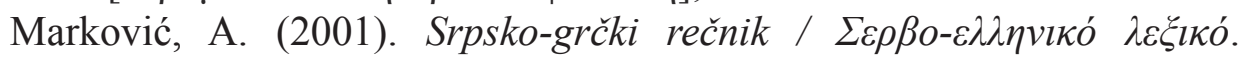

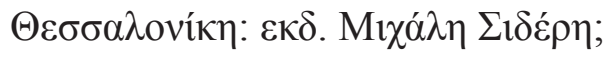

Matešić, J. (1982). Frazeološki rječnik hrvatskoga ili srpskoga jezika. Zagreb: Školska knjiga;

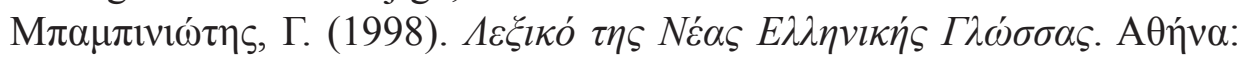

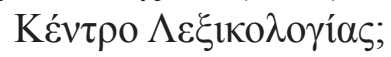

Otašević, Đ. (2012). Frazeološki rečnik srpskog jezika. Novi Sad: Prometej. Rečnik srpskohrvatskoga književnog jezika I-VI (1967-1976). Novi SadZagreb: Matica srpska, Matica hrvatska (u daljem radu RMS6);

Rečnik srpskog jezika (2007). Novi Sad: Matica srpska (u daljem radu RMS1); 


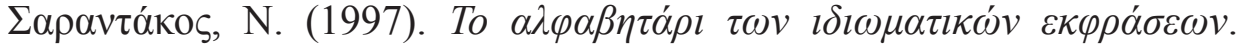

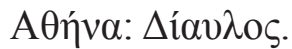

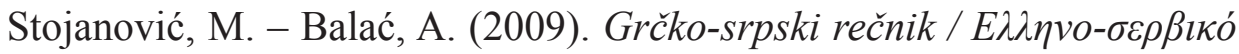

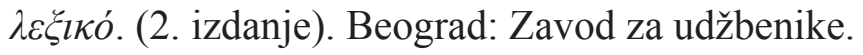

\section{Literatura}

Dragićević, R. (2007). Leksikologija srpskog jezika. Beograd: Zavod za udžbenike.

Đorđević, R. (2004). Uvod u kontrastiranje jezika. Beograd: Filološki fakultet Beogradskog fakulteta.

Kamings, E. (2004). Sve o simbolima. Beograd: Narodna knjiga Alfa.

Kövecses, Z. (2010). Metaphor. Oxford: Oxford University Press.

Matešić, J. (1982). Frazeološki rječnik hrvatskoga ili srpskoga jezika. Zagreb: Školska knjiga.

Mršević-Radović, D. (2008). Frazeologija i nacionalna kultura. Beograd: Društvo za srpski jezik i književnost Srbije.

Mršević-Radović, D. (1987). Frazeološke glagolsko-imeničke sintagme u savremenom srpskohrvatskom jeziku. Beograd: Filološki fakultet.

Mušović,A. (2002). Somatske frazeološke jedinice za izražavanje emocija i njihova sintaksicka funkcija. Kosovska Mitrovica: Filozofski fakultet.

Ristić, G. (2013). Somatizmi u nemačkoj i srpskoj frazeologiji. Novi Sad: Filozofski fakultet.

Trivić, A. (2015). Leksičko-semantička analiza somatizma u frazeologiji savremenog španskog i srpskog jezika: kontrastivni pristup. Kragujevac: Filum. (neobjavljena doktorska disertacija)

Šipka, M. (2001). Frazemi gestovno-mimičnog porekla. U Južnoslovenski filolog, LVII. Beograd: SANU i Institut za srpski jezik SANU, 41-52.

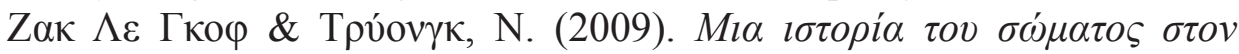

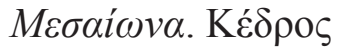

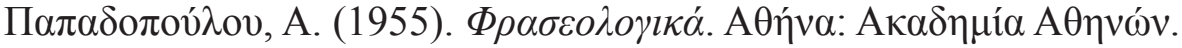

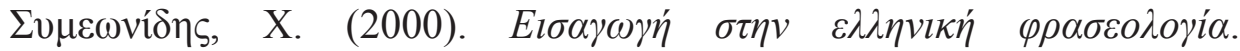

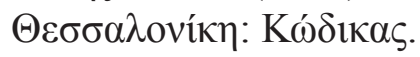


Ivana S. Milojević

\section{Summary \\ IDIOMS RELATED TO THE LEXEME HAND IN SERBIAN AND GREEK LANGUAGES}

The basic purpose of this paper is to analyze a number of Serbian and

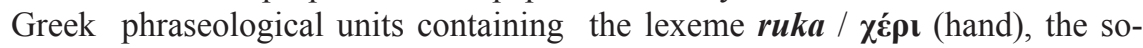
called somatism. A comparative and conceptive analysis is performed by means of drawing attention to corresponding and/or possible translation equivalents in the contemporary Serbian and Greek language. A classification and systematization of the selected idiomatic expressions according to their semantic fields (both positive and negative ones) is undertaken in order to provide a broader and much more clearer picture of the degree of the concordances as well as disagreements amongst them. The attention is predominantly paid to the lexeme hand which could be replaced in Serbian in some phraseological units with several other somatism (such as šaka, pesnica) without any significant change of their meaning.

Relying on our aforemention analysis and its final results it can be concluded that there is a large number of idiomatic expressions containing the lexeme hand which are discongruent, i.e. the degree of their semantic concordances is rather large, especially if we bear in mind expressing negative emotions and emotional ranks in the Serbian language (70\%) in comparison to the Greek language $(68,9 \%)$. Another large percentage $(32,5 \%)$ concerns the so-called zero semantic equivalency which means that there are no semantic agreements amongst the Serbian and Greek idiomatic expressions. In only a small number of cases $(20 \%$ respectfully) one can notice a complete (or absolut) semantic concordance, while in $47,5 \%$ of the cases a partial semantic equivalency is registered.

Key words: somatism, ruka / $\chi \varepsilon ́ \rho l$, contrastive and conceptual analyses, positive semantic field, negative semantic field, Serbian, Greek. 